\title{
Nurses Perception of Biological Risk
}

\author{
Rosa Elvira Minchala Urgilés ${ }^{1}$, Ángel Efraín Palaguachi Tenecela ${ }^{1}$, Luis Francisco Altamirano Cardenas ${ }^{1}$, \\ Pedro Carlos Martínez Suárez ${ }^{2,3}$, Elvia Narcisa Godoy Durán ${ }^{1}$, Andrés Alexis Ramírez-Coronel ${ }^{1,2}$. \\ ${ }^{1}$ Faculty of Nursing, Catholic University of Cuenca, Azogues Campus \\ ${ }^{2}$ Psychometrics Laboratory of the Centre for Research, Innovation and Technology Transfer \\ ${ }^{3}$ Faculty of Clinical Psychology of the Catholic University of Cuenca
}

\begin{abstract}
Biohazard perception is a process in which the sense organs interact with microorganisms that can cause tissue or multi-organic damage. The risk of infection by biological agents is recognized as one of the most important, especially in nursing professionals. Objective: To identify the perception of nursing personnel on biological risk, in the Vicente Corral Moscoso Hospital, Cuenca-Ecuador. Methodology: Cross-sectional, descriptive observational research with a quantitative approach. The sample was 164 nurses. A questionnaire validated in Cuba was used for data collection, and the processing and analysis of the results was carried out in the SPSS v25 programme. Results: $59 \%$ were between 20 and 30 years old, $92 \%$ were female, $50 \%$ were single and $44 \%$ were nursing professionals. In relation to the individual, $60 \%$ have received little training on biological risk, 59\% have received protective measures. In the nature of the risks, 92\% do consider the consequences of biological risks, 79\% report little information on accidents and incidents in the institution. In risk management, 68 per cent report that few managers and supervisors are aware of current biosecurity resolutions. Conclusion: Nurses have received little biohazard training, are unaware of some of the protective measures and accidents and incidents in the facility. Few administrators and supervisors are trained in bio-safety.
\end{abstract}

Keywords:- Perception, biohazard, nursing staff.

\section{INTRODUCTION}

In recent years, health professionals are constantly exposed to various contaminants that endanger their health, among which is biological risk, defined by the WHO (1) as 'the possible exposure to micro-organisms that give rise to disease, caused by work activity'. Fang (2): The risk of infection by biological agents is recognized as one of the most important risks for health care personnel, particularly nurses, because in their role as clinical specialists they have direct and continuous contact with the patient, carrying out daily care activities that involve procedures of all kinds, and this implies exposure to pathogenic agents.

The International Labour Organization (3) states that the new biological risks are generated by the demands of employment and the pressure that is increasing to meet the needs of the modern institution and population, and is due to the application of new technologies, including health personnel, who are mostly exposed to the environment, to transmissible diseases and when protective barriers for personnel are not available.

Biological risk is the exposure of a biological agent that can generate a contagious and infectious process in the individual or health personnel, originating from the colonization of micro or macro organisms, which are harmful to the individual (4). When it enters the human body, it triggers an adverse effect depending on the causal agent; it is transmitted by secretions or substances from the body of an affected individual. In addition, the accidentalness generated by uncontrolled exposure to biological risk is a harmful situation for health workers since it produces serious and fatal diseases, among the most important of which are hepatitis B, hepatitis C, HIV and tuberculosis $(5,6)$.

Biological risk is currently a public health problem at both national and international level, and the safety and health of professionals at work is part of social rights (7). The occupational health department should therefore be responsible for generating activities aimed at promoting and protecting workers through prevention and the use of protective barriers, as well as controlling the pathologies that are caused by occupational accidents (8). Sanlés (9), reports a study with 1342 accidents of biological risks declared in the Preventive Medicine Service of the Puerto Real University Hospital, where health professionals, Nursing graduates represent almost half of the declared exposures (49\%). It is followed by the Medical group with $19 \%$ and Nursing Assistants with $16 \%$.

Perception is called a psychological process where the senses interact, it is the obtaining of nervous impulses by means of images, impressions or sensations of the environment in which a person develops. In this way the individual sends a response as a result $(10,11)$. Goldstein (12) indicates that the reason why individuals study perception is to satisfy the intellectual curiosity of an event that occurs in a person's life such as illness or injury. The process of perception involves capturing a stimulus, its recognition and its action.

Carranza in his study "Knowledge of the nursing personnel on protective barriers of biological risk in the emergency service Hospital María Auxiliadora - 2015; refers that $23 \%$ do not know about the protective barriers in the prevention of biological risk, being considered a serious problem, by virtue that the health personnel must be completely qualified to guarantee optimal conditions of care at professional level as well as to the user (13). In a 
study carried out in health institutions in the province of Pinar del Río - Cuba, it is reported that "95.4\% of those injured due to biological risk presented lesions on their hands, fundamentally with intact skin", due to the fact that the activities are carried out with their hands (14).

Vieytes S., in the literature review study on "Knowledge of biohazard accidents in students and health care workers" reports that there is a lack of knowledge and obstinacy on the part of professionals, such as students, in the correct use of individual protective clothing, as well as the respective notification at the time of an accident (15). Rodriguez in his study in Bucaramanga, describes that the self-care shown by nursing students is not regular, a percentage of $79.1 \%$ indicates that at the time of their training practices, their vulnerability to infection increases (16).

Among the biosecurity principles that should be complied with are: universality, use of barriers, means of eliminating contaminated material and risk evaluation (17). It is important to take into account the biosecurity standards (18).

> Avoid contact with secretions (blood and other body fluids of the patient coming into care).

$>$ Always wear protective clothing to avoid contamination with patient's secretions.

$>$ Wash hands before and after procedures, contact with secretions and the patient's environment.

$>$ Use biological waste collection containers properly to avoid damage or injury to the skin.

The organic law of public service (LOSEP) in its supplemental record 294, 2010, describes that: the public service will help the personnel to their permanent improvement, because it is necessary a constant education on the part of the professionals to be able to improve their knowledge on new protocols, techniques, instruments or theories (19).

Considering the statistics from the studies on biological risk in nursing personnel and the fact that they are a vulnerable group in the transmission of infectious diseases, it is important to apply preventive measures to reduce risks and accidents in health personnel. The control of biological risk in the personnel is one of the actions to be taken into account by the authorities of the health institutions; for this reason the purpose of the investigation was: To identify the perception of the nursing personnel on exposures to biological risk in the Vicente Corral Moscoso Hospital, Cuenca - Ecuador; 2020.

\section{METHODOLOGY}

It is a non-experimental study, with a quantitative and cross-sectional approach. The research was carried out with the nursing staff (professional nurses, interns and nursing assistants) of the Vicente Corral Moscoso Hospital in the city of Cuenca, from September 2019 to February 2020, to measure the perception of biological risk. With a population of 461 people, of which 164 were selected through probability sampling, taking into account $95 \% \mathrm{CI}$ and $79 \%$ prevalence (20). It was approved by the manager, the teaching department of the institution and the Bioethics Committee.

For data collection, the survey was used through an internationally validated test by Dailín Cobos Valdés (Biological Risk Perception), (20), which consists of 4 dimensions: general data, risk management perception, variables related to the individual and related to the nature of the risks, which was filled out after signing the informed consent. The statistical program SPSS Version 25 was used for data analysis and tabulation, where data are presented with frequencies and percentages.

\section{RESULTS}

The staff selected in the study sample is between 20 and 65 years old.

\begin{tabular}{|c|c|c|c|}
\hline Variables & Indicators & $f$ & $\%$ \\
\hline \multirow{4}{*}{ Age } & $20-30$ & 97 & 59 \\
\hline & $31-40$ & 42 & 26 \\
\hline & $41-50$ & 13 & 8 \\
\hline & $51-65$ & 12 & 7 \\
\hline \multirow{2}{*}{ Gender } & Male & 14 & 8 \\
\hline & Female & 150 & 92 \\
\hline \multirow{5}{*}{ Marital status } & Single & 82 & 50 \\
\hline & Married & 56 & 34 \\
\hline & Divorced & 12 & 7 \\
\hline & Free Union & 11 & 7 \\
\hline & Widow & 3 & 2 \\
\hline \multirow{3}{*}{ Occupation } & Professional & 72 & 44 \\
\hline & Internal & 49 & 30 \\
\hline & Assistant & 43 & 26 \\
\hline & & 164 & 100 \\
\hline
\end{tabular}

Table 1:- Distribution according to sociodemographic data of nursing personnel. 
The table shows that $59 \%$ are in the $20-30$ age range, $92 \%$ are female, $50 \%$ are single and $44 \%$ are nursing professionals. In the study sample, young professional staff, mostly women, were observed.

\begin{tabular}{|c|c|c|c|}
\hline $\begin{array}{c}\text { Variables } \\
\end{array}$ & Indicators & $\mathbf{f}$ & $\%$ \\
\hline \multirow[t]{3}{*}{ Have you received basic training on biosecurity? } & No & 15 & 9 \\
\hline & Very little & 90 & 55 \\
\hline & Enough & 59 & 36 \\
\hline \multirow[t]{3}{*}{ How long have you been in that activity? } & 1 year & 52 & 32 \\
\hline & 1 to 5 years & 67 & 41 \\
\hline & More than 5 years & 45 & 27 \\
\hline \multirow{3}{*}{$\begin{array}{l}\text { Have you received specific training related to the } \\
\text { biological risk of the activity you are } \\
\text { undertaking? }\end{array}$} & No & 17 & 10 \\
\hline & Very little & 98 & 60 \\
\hline & Enough & 49 & 30 \\
\hline \multirow{3}{*}{$\begin{array}{l}\text { Has the specific biohazard training in your } \\
\text { activity helped you in practice? }\end{array}$} & No & 8 & 5 \\
\hline & A little bit. & 65 & 40 \\
\hline & Completely & 91 & 55 \\
\hline \multirow{3}{*}{$\begin{array}{l}\text { Have the biological hazards to which you are } \\
\text { exposed and their health consequences been } \\
\text { explained to you? }\end{array}$} & No & 10 & 6 \\
\hline & Of some & 82 & 50 \\
\hline & Of all & 72 & 44 \\
\hline \multirow{3}{*}{$\begin{array}{l}\text { Has the importance of taking measures to protect } \\
\text { against this type of risk been explained to you? }\end{array}$} & No & 4 & 2 \\
\hline & Of some & 87 & 53 \\
\hline & Of all & 73 & 45 \\
\hline \multirow{3}{*}{$\begin{array}{l}\text { Do you consider yourself prepared to decide } \\
\text { whether or not to take risks consciously? }\end{array}$} & No & 11 & 7 \\
\hline & Only for some cases & 97 & 59 \\
\hline & For all cases & 56 & 34 \\
\hline \multirow{3}{*}{$\begin{array}{l}\text { Have the measures for protection against these } \\
\text { risks been specified to you? }\end{array}$} & No & 5 & 3 \\
\hline & For some & 96 & 59 \\
\hline & For all & 63 & 38 \\
\hline \multirow{3}{*}{$\begin{array}{l}\text { Do you think that knowing the biological risks to } \\
\text { which you are exposed gives you more control } \\
\text { over them? }\end{array}$} & No & 1 & 1 \\
\hline & Sometimes & 79 & 49 \\
\hline & Always & 84 & 51 \\
\hline \multirow{4}{*}{$\begin{array}{c}\text { Do you consider that the protection measures } \\
\text { foreseen for your activity are really applicable } \\
\text { and allow you to have more control over the } \\
\text { risks? }\end{array}$} & No & 3 & 2 \\
\hline & Sometimes & 88 & 54 \\
\hline & Always & 73 & 44 \\
\hline & & 164 & 100 \\
\hline
\end{tabular}

Table 2:- Nursing staff perception, related to the individual.

Regarding the perception of the nursing staff, related to the individual, $60 \%$ have received little training on biological risk according to the activity, 59\% consider themselves prepared to assume the risks in some cases, 59\% report having received protective measures, $55 \%$ of the staff have received biological safety training. Fifty-five per cent report that specific training on biological risk has helped them in practice, 54\% say that there are few protective measures for risk control, and 53\% mention the importance of taking some protective measures. The results show that they are young personnel, who have worked from 1 to 5 years and that only half of them received training, that they do not receive protective measures and are prepared to assume biological risks. 
ISSN No:-2456-2165

\begin{tabular}{|c|c|c|c|}
\hline Variables & Indicators & $\mathbf{f}$ & $\%$ \\
\hline \multirow{3}{*}{$\begin{array}{l}\text { Are you aware of the accidents and incidents } \\
\text { that have occurred in your entity associated } \\
\text { with biohazard? }\end{array}$} & No & 13 & 8 \\
\hline & Some & 130 & 79 \\
\hline & All & 21 & 13 \\
\hline \multirow{3}{*}{$\begin{array}{l}\text { Do you know the accidents and incidents that } \\
\text { have occurred in your workplace related to } \\
\text { biohazard? }\end{array}$} & No & 15 & 9 \\
\hline & Some & 122 & 74 \\
\hline & All & 27 & 17 \\
\hline \multirow{3}{*}{$\begin{array}{l}\text { Do you know the consequences of biohazard } \\
\text { exposure on your activity? }\end{array}$} & No & 3 & 2 \\
\hline & Some & 110 & 67 \\
\hline & All & 51 & 31 \\
\hline \multirow{3}{*}{$\begin{array}{l}\text { Do you consider that these consequences can } \\
\text { affect your health? }\end{array}$} & No & 1 & 1 \\
\hline & I have no knowledge & 13 & 8 \\
\hline & Yes & 150 & 91 \\
\hline \multirow{3}{*}{$\begin{array}{l}\text { Does the training you receive adequately } \\
\text { illustrate the consequences of hazardous } \\
\text { events that may occur in your activity? }\end{array}$} & No & 21 & 13 \\
\hline & Some & 115 & 70 \\
\hline & All & 28 & 17 \\
\hline \multirow{3}{*}{$\begin{array}{l}\text { Do you know the probability of occurrence of } \\
\text { possible hazardous events or increased } \\
\text { biological risk in your activity? }\end{array}$} & No & 7 & 4 \\
\hline & Only in some cases & 120 & 73 \\
\hline & If in all cases & 37 & 23 \\
\hline \multirow{3}{*}{$\begin{array}{l}\text { Have you analyzed the probability of } \\
\text { occurrence of possible hazardous events or } \\
\text { increased biological risk in your activity? }\end{array}$} & No & 11 & 7 \\
\hline & Some & 121 & 74 \\
\hline & All & 32 & 19 \\
\hline \multirow{4}{*}{$\begin{array}{l}\text { Does the training you receive adequately } \\
\text { illustrate the likelihood of hazardous events } \\
\text { that may occur in your activity? }\end{array}$} & No & 11 & 7 \\
\hline & Sometimes & 119 & 73 \\
\hline & Always & 34 & 20 \\
\hline & Total & 164 & 100 \\
\hline
\end{tabular}

Table 3:- Nurses' perceptions, related to the nature of the risks.

In relation to the Perception of the nursing personnel, with the nature of the risks; $91 \%$ do consider that the consequences can affect health, 79\% refer little information on accidents and incidents on the part of the institution, 74\% indicate knowing some accidents and incidents occurred at work related to biological risk, just as $74 \%$ describe a probability of occurrence of dangerous events, $73 \%$ consider that only sometimes the training has adequately illustrated the probabilities of dangerous events that can occur in their activity.

\begin{tabular}{|c|c|c|c|}
\hline Variables & Indicators & $\mathbf{f}$ & $\%$ \\
\hline \multirow[t]{3}{*}{ Is there a Biosafety policy? } & No & 7 & 4 \\
\hline & Yes and no & 92 & 56 \\
\hline & Yes, and if you know & 65 & 40 \\
\hline \multirow[t]{3}{*}{ Is there a biosecurity structure? } & No & 9 & 5 \\
\hline & Sometimes & 98 & 60 \\
\hline & Always & 57 & 35 \\
\hline \multirow[t]{3}{*}{ Is biosecurity integrated into all organizational processes? } & No & 7 & 4 \\
\hline & Only in some processes & 103 & 63 \\
\hline & In all & 54 & 33 \\
\hline \multirow{3}{*}{$\begin{array}{l}\text { Is the management aware of the current biosecurity } \\
\text { resolutions? }\end{array}$} & No & 13 & 8 \\
\hline & Some & 112 & 68 \\
\hline & All & 39 & 24 \\
\hline
\end{tabular}


ISSN No:-2456-2165

\begin{tabular}{|c|c|c|c|}
\hline \multirow[t]{3}{*}{ Is the company's own biosafety documentation prepared? } & No & 16 & 10 \\
\hline & Some & 100 & 61 \\
\hline & All & 48 & 29 \\
\hline \multirow[t]{3}{*}{ Do workers know the biosafety policy? } & No & 27 & 16 \\
\hline & Some & 90 & 55 \\
\hline & Most & 47 & 29 \\
\hline \multirow[t]{3}{*}{ Do the workers know the biosafety structure? } & No & 22 & 13 \\
\hline & Some & 110 & 67 \\
\hline & Most & 32 & 20 \\
\hline \multirow{3}{*}{$\begin{array}{c}\text { Is biosafety integrated into all processes of the } \\
\text { organization? }\end{array}$} & No & 9 & 5 \\
\hline & Only in some processes & 106 & 65 \\
\hline & In all & 49 & 30 \\
\hline \multirow[t]{3}{*}{ Do the personnel feel confident about biosafety? } & No & 22 & 13 \\
\hline & Sometimes & 110 & 67 \\
\hline & Always & 32 & 20 \\
\hline \multirow[t]{3}{*}{ Are supervisors trained in Biosecurity? } & No & 21 & 13 \\
\hline & Sometimes & 103 & 63 \\
\hline & Always & 40 & 24 \\
\hline \multirow{4}{*}{$\begin{array}{l}\text { Do supervisors provide a specific response to those } \\
\text { supervised based on knowledge and individuality? }\end{array}$} & No & 21 & 13 \\
\hline & Sometimes & 103 & 63 \\
\hline & Always & 40 & 24 \\
\hline & Total & 164 & 100 \\
\hline
\end{tabular}

Table 4:- Nursing staff perception, related to risk management.

In the table on Nurses' Perception of Risk Management, it is observed that $68 \%$ state that few managers are aware of current biosecurity resolutions, $67 \%$ indicate little confidence in biosecurity and institutional structure, $63 \%$ respond that only some of the supervisors are trained in biosecurity and the same percentage (63\%) mention that supervisors provide a response based on knowledge and individuality.

\section{DISCUSSION}

Biological risks are exposures to pathogenic microorganisms that can lead to disease and endanger the health or life of the individual, which are generated in the workplace. Transmission occurs through the respiratory, digestive, blood, skin or mucous membranes. It is considered important to know and understand the biosafety protocols, to prevent through immunizations, to comply with personal hygiene rules, to use adequate personal protection equipment, and thus to avoid contagion through poor management.

The study was conducted on 164 nursing staff distributed among graduates, interns and nursing assistants at the Vicente Corral Moscoso Hospital, Cuenca-Ecuador, 2020; the predominant age was 20 to 30 years, with $59 \%$, $92 \%$ of whom were women. Within the marital status, $50 \%$ are single, and according to occupation, $44 \%$ are nursing graduates, $30 \%$ are interns, and $26 \%$ are nursing assistants, compared to the study by Padrón (14) in 2017, with 87 people from the health institution in the province of Pinar del Río, where the age range was predominantly 25-34 years, and $78 \%$ were women.
As for the variable perception related to the individual, $55 \%$ of the population has received little training, as it corresponds to Moreno's study (21) on the perception of biological risk by students of Nursing degree, explains that untrained students have less knowledge of the damage that biological risk can cause, concluding that the two studies are similar.

With respect to the variable related to the nature of the risks, it is worth mentioning that $79 \%$ are aware of some of the accidents and incidents that have occurred at the institution, with a coincidence of risk factors, if compared to the study carried out by Padrón Y., (14) where the occupational accident rate due to biological risks in health institutions, 95.4\% present injuries to hands, the highest risk of contact with blood and its derivatives.

Fang (2) in "Perception of nursing personnel on biological risks -2015" points out that $65 \%$ of the population studied is unaware of biological safety protocols such as notification forms, which is closely related to the study variable of risk management, where $56 \%$ of a safety policy exists but is not known. Ruiz de Somocurcio, in his study with 517 nursing workers, states that there are significant differences in the level of knowledge according to the variables of occupational group, age, time working in the hospital, sex by occupational group, sex by age and having received an induction into the workplace.

Inadequate working conditions, such as high work pressure, lead to accelerated decision-making and increase the likelihood of mistakes. These circumstances, coupled with a lack of confidence in reporting and fear of consequences, have a significant physical and emotional impact (23). Reflection is needed on the risks of the 
incidence of accidents involving biological materials to which health care workers are exposed, in addition to the application of the knowledge received on preventive measures (24). Nursing work is still precarious and requires permanent investment (25).

Having information on the accident rate, the existing risks and the professional profile of the injured parties and making them known is one of the most important elements in achieving a change in the preventive culture. Without a good knowledge of them on the part of health managers, the problem will not be properly recognised and preventive measures will not be put in place to reduce the accident rate (9).

\section{CONCLUSIONS}

Promoting and ensuring the safety of health personnel and patients, through the use of preventive measures, in health institutions is of vital importance to prevent biological risks, work accidents, adverse events, or infectious diseases. In this research, of the nursing staff studied, the highest percentage is young personnel from 20 to 30 years of age, with a predominance of women, single and professional nurses, who work from 1 to 5 years. With respect to the perception of the individual, it was determined that nurses have received little training on biological risk according to the activity they perform, but are considered prepared to assume the risks in only a few cases; they reported little training on biological protection and safety measures. In their perception of the nature of the risks, nurses consider the consequences of the health risks, report little information on accidents and incidents, describe little probability of the occurrence of hazardous events, and consider that only sometimes has training illustrated the probability of hazardous events.

In the perception of risk management, it is shown that few managers or supervisors who have biosafety knowledge and confidence in biosafety in addition to structure recognize that only some of them are trained. It is considered important to promote and encourage administrative and nursing personnel to undergo training and self-education on biological risk management, in order to comply with biological safety protocols and consequently reduce adverse events. It is also important to improve the work environment to avoid errors and encourage the reporting of adverse events for decision making.

\section{ACKNOWLEDGEMENT}

To the authorities and nursing staff of the Vicente Corral Moscoso Hospital in the city of Cuenca-Ecuador, to the nursing faculty and psychometric laboratory of the Catholic University of Cuenca.

\section{REFERENCES}

[1]. World Health Organization [Online].; 2019. Available from: https://www.who.int/topics/vaccines/es/.

[2]. Fang M, Meléndez M, Rosalinda G, Aguilera P, Aguilera A, Ortega R. Nurses' perceptions of biological risks. CONAMED. 2015; 20(1):12-16. https://dialnet.unirioja.es/servlet/articulo?codigo=729 1381

[3]. International Labour Organization. [Online].; 2010. Available https://www.ilo.org/wcmsp5/groups/public/-ed_protect/---protrav/--safework/documents/publication/wcms_124341.pdf.

[4]. Bravo S, Diaz D. Biological risk in health institutions: control and precautions in patient care. Rev. Científica Villa Clara. 2016; 20(2).

[5]. Diaz A, Vivas M. Biological risk and biosafety practices in teaching Rev. Facultad Nacional de Salud Pública. 2016; 34(1):62-69.

[6]. González Acevedo H, Cácua Rojas E, Rueda Correa G, Silva Giraldo CA, Pérez Olmo LM. Design of an intervention model for exposure and control of biological risk in the nursing staff of the Bucaramanga emergency clinic. 2018; 7(5):74-84.

[7]. Galán G. Justiciability of social rights: A brief introduction to an integrated system of "multi-level" protection. Ius. Humani, Rev. de Derecho. 2016;5(149).

[8]. Canales M. Working conditions for nurses in Chile. Rev. Enfermería Universitaria. 2016; 13(3).

[9]. Sanlés Pérez M. Study on biological risk exposures in a health centre, University of Cadiz, Spain. 2016. https://dialnet.unirioja.es/servlet/tesis?codigo $=50818$

[10].Pérez Gardey A. Definition of perception [Online]. 2012. Available from: https://definicion.de/percepcion/.

[11].Forigua J. Attention, sensation and perception. First edition. Mora E; editor. Bogotá: University Foundation of the Andean Area; 2018.

[12].Goldstein B. Sensation and perception. Eighth ed. Paperback; editor. Mexico: Cengage learning; 2011.

[13].Carranza. Cybertesis. [Online]; 2016. Available from: http://cybertesis.unmsm.edu.pe/handle/cybertesis/524 4.

[14].Padrón Y, Moreno S, Márquez A, González L, Pérez F. Occupational accidents in exposure to biological risks in health institutions. Rev. Ciencias Médicas de Pinar del Río. 2017; 21(2). http://scielo.sld.cu/scielo.php?pid=S156131942017000200008\&script=sci_arttext\&tlng=en

[15].Vieytes S, García K, Numpaque A. Knowledge of biohazard accidents in students and health care workers. Ciencia y Salud Virtual. 2017 Julio; 9(2).

[16].Rodríguez M, Trespalacios V, Gutiérrez M, Villamizar M, Consuelo C. Self-care agency, knowledge, attitudes and practices of biological risk in nursing students 
[17].Marziale MH, Rocha FL. Influence of the organization on the occurrence of occupational accidents involving exposure to biological material. Revista latino-americana de enfermagem. 2013; 21:199-206.

[18].Castro A, Respecte J, Sotallan Y. National University of Cuyo. [Online].; 2018. Available from: http://bdigital.uncu.edu.ar/12769.

[19].Gir E, Netto JC. Accidents with biological material and immunization against hepatitis B among students from the health area. Revista Latino-Americana de Enfermagem. 2008;16(3):401-406.

[20].Cobos D, Vilariño C, Vazquez Y, Ramos M, Torres A. Perception of biological risk in two health science entities in Holguin. Medicina y seguridad del trabajo. 2016; 62(244): 212-222.

[21].Moreno C, Puig M, Falco A, ¿Lluch M, Casas I, Roldán J. What is the biological-risk perception of nursing students? Rev. Latino-Americana de Enfermagem. 2016; 24; 1-9.

[22].Jorge A. Ruiz de Somocurcio Bertocchi; Knowledge of biosecurity measures in health personnel. Rev. Horizontes Médicos. 2017; 17(4).

[23].Fernández-García E, Porcel-Gálvez A, BarrientosTrigo S, Blanco-Naranjo, O; Gil-García, E. Adverse events: risk to the health of patients and nursing professionals. Metas enferm.2019; 22(10): 58-66.

[24].Guimarães de Carvalho L, Grego Maia L, Valverde S. Association of recurrence of accidents with biological materials with the profile of health workers. Rev. Index Enferm. 2019;28(1).

[25].Shoji, S. Impact of the work environment on the health-disease process of medical specialty center nurses. REME Rev. min. Enferm.2020; 19(1): 43-48. 